\title{
HOW TO EVALUAT EFFICIENCY OF THE EXPORT STRATEGIES
}

\author{
GIORGI GAGANIDZE \\ Professor \\ Ivane Javakhishvili Tbilisi State University, Georgia \\ giorgi.gaganidze@tsu.ge \\ BADRI RAMISHVILI \\ Associate Professor \\ Ivane Javakhishvili Tbilisi State University, Georgia \\ badri.ramishvili@tsu.ge
}

\section{KEYWORDS: EXPORT STRATEGY FORMULATION AND MANAGEMENT, EVALUATION OF THE EFFICIENCY OF THE EXPORT STRATEGIES}

\section{INTRODUCTION}

In the period of Globalization as the intensity of competition increased, utilization of international experience and of efficient competitive methods is becoming increasingly important. The traditional paradigm of the competitive advantage, which stated that the security of the domestic market is the most important for the competitive advantage, is becoming obsolete. Thus, the representatives of Business and Academic communities are changing their attitudes toward export. Traditionally export was reviewed as one opportunity to increase sales where higher economic risks compensated through higher fianacial premium due to the higher export prices. This reality is changing and attitudes toward the exports are becoming more pragmatic. "Importantly, export market development has become more a matter of survival than choice for many firms that face challenging economic conditions" [1]. This statement clearly revealed the changing attitude toward exports, as the export from the one of the ways for development became the way to survive in the tough competitive environment. There is no sense to additionaly discuss here that export creates new jobs, decreases the threat of the currency crisis, etc. The aim of the article is to review the specific terms for the formulation and management of the export strategies, review their place in the sets of the devepolment strategies and create criteria for evaluating efficiency.

\subsection{Types of the Export Strategies}

Reviewing the Export Strategies is very important for distinguishing Strategies on the Macro and Micro level or the firm strategies needed for sustainable development. It should be noted that in the current context strategies on the macro level are less popular and the major emphasis is put on the trade facilitation activities. These topics would be reviewed later. Now we would concentrate on the practical issues of the Export Strategies. As we already mentioned, the Export Strategies are becoming a choice, a way to survive in the tough competitive environment. Firms are urged to find every way for growth and thus explore the Export Strategies. Clear, that the Export Strategies are theoretically and practically well developed issues, but the dynamism born by Globalization demands some changes. In the Export Strategies markets are important as well as the entry modes and the entry time. There should be specifically defined markets, where geographical aspects are as important as a good definition of market segments. These activities are leading to succesfull export strategies. In this direction theoreticians are offering different ways to the managers.

Lately the definition of the Trade Intensvity Index has become popular. This topic was reviewed in the Author's previous article "Export Potential and Competitive Advantage [4].

Trade Intensification Index [1] should be used as an analytical tool for evaluating export potential of a country or a group of countries. Index lij is defined based on the Xij- I country export in the $\mathrm{j}$ country; $\mathrm{Xij}$ I country total export; $\mathrm{Mj}-\mathrm{j}$ country total imports; M-world imports. $l i j=(X i j / X i) /(M i j / M)$. If lij is higher than 1 , this means that your trade partner is more important to you than you to the trade partner. If lij equals 1 , your exports are equivalent to your export potential and import potential of the partner. If lij is less than 1 , your export potential is underutilized. The underutilized export potential could be defined as the difference between the exports in case of lij equals one and the actual exports. It should be noted that this method has a practical value, but this value is transformed in the competitive advantage only in certain circumstances. First of all, this is the match between the export products and import level of this product in the potential importing country. Thus the Trade Intensification Index defines the importance of the Trade partner in general and is a valid indicator for planning activities on the macro level, such as creation of the trade regimes, creating tradeoffices, planning trade missions.

On the micro level it would be better to review more sophisticated indexes. Thus we could modify the Trade Intensification Index regarding the exporting product group. In this case we"ll define the Product Group Intencification Index (the index is introduced by Author) as Eaij=(Xaij/Xai) (Maj/Ma), where, 
Xaij - $\mathrm{i}$ country export of a product in the $\mathrm{j}$ country

Xai - i country total export of a product

Maj - a product import in j country

Ma - a product world import

A product considered on the 4 digit level of the Harmonized System should be noted that calculations on the 6 or 8 digit level would give a better picture. Research provided by this methodology gives an opportunity to evaluate export potential in different countries, thus having the 3 or 4 choices preference would be given to the choice with the highest export potential. This methodology should be reviewed as the most general and thus should be used on the initial stage of export strategy. After the definition of the country with the highest export potential the target market should be defined - the consumer or the industries should be served. These markets differ dramatically, if we are exporting on the consumer market export could be defined as the Function Xij=f(Yj,Pj,Fj,Rj,Dij), where

$$
\begin{aligned}
& \text { Xij - i country export in country j } \\
& \mathrm{Yj}-\mathrm{j} \text { country population } \\
& \mathrm{Pj}-\mathrm{j} \text { country GDP per capita } \\
& \mathrm{Fj} \text {-historical relations between } \mathrm{i} \text { and } \mathrm{j} \text { countries, such as }
\end{aligned}
$$
dominion-metropolia, part of one country previously, same military-political block members.

$\mathrm{Rij}$ - trade regimes between $\mathrm{i}$ and $\mathrm{j}$ country, ordinary trade, MFN, GSP or FTA.

Dij - distance between two countries measured as the distance between export and import custom terminals.

This function could be considered as the most general and further research is needed to create the econometric model.

When exporting the industrial markets in the function, it would be necessary to make some changes, as the population criteria and GDP per capita would be changed by lj total industrial output and Ej industrial export. These criteria are very important if you are going to export semi finished products. These general attitudes are forming the basis of evaluation of export potential and the level of its utilization. It should be noted that these researches couldn't guarantee success of the export strategy. In the first place, the success of the export strategy depends on how exporting firm is going to use competitive advantage. Thus, only the competitive advantage leads to successful results.

\subsection{Role and place of export strategy in the modern global competition}

The success of any strategy is determined by utilization of the competitive advantage, thus the better utilized compatitive advantage is the more successful the export strategy is. The competitive advantage is considered the basis for the strategy. It should be noted that the succesfull export strategy could serve as a source of the competitive advantage. For example, some production was exported based on the high quality of the product increased sales volume and gave the firm the opportunity to seek the economy of scale which by itself creates the new competitive advantage and gives the opportunity of entering new export markets by lowering prices.

In exporting consumer products the most important is the creation of the value chain. Value chain would serve as the basis for the competitive advantage. Thus we could consider different options- direct and indirect exports, strategic partnership or alliances.

Also export strategies could serve as a tool to lead for import substitution - for which the mutual formation of export promotion and import substitution strategies should be made. At the same time we should take into consideration that in the event of joint formation of these two strategies they will have the mutual forcing effect. For example, when developing a strategy for export promotion, firstly the better delivery of the given goods to the local market will take place and another similar strategy will give the signal to a whole industrial chain of values which can result in local production of the necessary inventory. The cluster effect is also considerable in terms of development of the adjacent production. Successful Imports Subtitution Strategy can in turn develop into export strategy. Based on the surveys of Porter, receiving of the product by the foreign market is founded upon the success achieved in the local market. If we consider this approach as a priority, then the strategy of export promotion can become a continuation of successful import replacement strategy.

The strategy of export promotion often involves an innovative component as well. This, in turn, can be the basis for opening a new local market. In this case the replacement of imported substitutes will happen with a great possibility. That is why the good result will be reached through the joint development of the export promotion and the Import Replacement Strategies which might eventually become a foreign trade strategy.

In the export of industrial goods they are supplied directly to the industrial consumers where the most important topics are the production price, the readiness of the product to be industrially explored, supplying time and stability. The range of these factors differs from the factors considered previously (consumer products). Thus the importance of the general exporting strategies increases and the state support for the exporting strategies becomes vital. When we are considering succesful exporting strategies on the state level, first of all, we are considering exporting strategies utilized by Japan, Taiwan, Thailand, South Korea, China and Ireland. In any of these cases the export strategies based on the competitive advantage, mainly on the high volume of the hand jobs in the 
assembling plants, in combination with the high productivity and low labour costs. It should be noted that the combination of these factors also worked well in the high tech industries. Later the growth of the Irish exports also was based on the same factors in addition to the high emigration of Irish people (first of all in Great Britain and USA) and the perfect knowledge of the English language.

Even the simple analysis reveals that the export strategies on the macro level where clearly based on the existing competitive advantage. In the same manner we could review the export strategies on the micro level, where competitive advantage should be clearly defined. Thus the competitive advantage should be the basis of the export strategy and taking into consideration the fact, that globalization changed the type of competition, the export strategies should be globally oriented. Many researchers are putting the equal sign between this statement and the possibility to produce products at low costs. This position is not right for every sector. It's right in the production of the mass products where the price competition plays a major role. Besides, there always exists niche demand and production which have the specific features, the export strategies for these products differed. In the modern global competition these specific features could be created based on the artistic factors. For example, while in the production of the mass building materials the major factors would be low production costs and low prices, the same production for the niche demand should have some unique characteristics, and should meet specific demands of the consumers.

Reviewing the export strategies on the macro level we should also review activities of the International Organizations. Regarding exporting strategies, first of all, we should consider International Trade Center, which supports creation of the export strategies through special Programme "Export led Poverty Reduction"[5]. Also it should be noted that the World Bank sectoral initiatives and researches are aiming at increasing export potential of the underdeveloped countries and the success of the Initiated by International Donors projects are fully depend on the receiving countries policies. If the country doesn't have the competitive advantage the participation of the International Donors couldn't change this reality and project will not be sustainable. The projects would be succesful if they are based on the existing or the potential competitive advantage.

\subsection{The Role of State in the formulation and realization of the Export Strategy}

There is an ongoing discussion of the role of the State in the formulation and success of the Export Strategies. We should make one note that the successful export strategy on the macro level means improved trade balance, higher growth of exports or declaring export as the major economic growth indicator and creating additional jobs. The Export Strategy on the macro level means the creation of the specific conditions for the production and exporting of some products, not creating special conditions for some firms. In this regard the macro Export Strategies should be oriented on the creation of trade facilitating conditions. More open trading regimes mean to remove barriers on the domestic market. From the 1990s the most popular is the idea that having only preferences couldn't be realistic, international trade is the two way traffic, thus we are using the term "Trade Facilitation" which covers some specific actions.

According to the World Bank research, "under the Trade Facilitation we consider any actions which decrease the export/import tariffs. The marginal effect of infrastructure improvement on exports appears to be decreasing in per capita income. In contrast, the impact of information and communication technology on exports appears increasingly important for richer countries. The trade facilitation measures can be undertaken along two dimensions: a "hard" dimension related to tangible infrastructure such as roads, ports, highways, telecommunications, as well as a "soft" dimension related to transparency, customs management, business management, and other institutional aspects that are intangible. "[3].According to the findings of this research in Georgia activities should be focused on the improvement of infrastructure and customsmanangement. For Georgian exporters the information support would be important, which should be focused on the specific markets rather than general. Thus we face two problems, the first is the cost efficiency and the second is the justice or is it fair to assist one exporter if there are hundreds of exporters? The solution of these problems should be based on the world experience. First of all effective mechanisms for Public Private co-operation should be created.

Such mechanisms are competitiveness Councills, Industry Associations, etc. Competitiveness Councills provide day-to day monitoring of the competitiveness of State, some industries, also they are facilitating the agreement between the State and the private sector regarding priorities. When such priorities are agreed, special market research activities would be undertaken and would solve the above mentioned problems.

Also we should review the use of informationcommunication technologies as the Special tool for the trade facilitation. In the modern service oriented economy it would be quite difficult to organize giant production facilities in Georgia, thus the orientation should be towards many small exporting companies, where access to the information resources is more valuable than low production costs.

World practice determined the advantage of the sectoral, rather then general export strategies. In this case sectors with the real or potential advantages are identified and supported export strategies in these sectors. In the Georgian reality these sectors could be sectors creating higher value added export products on the basis of the existing export products, such as production of jewellery, special batteries on the basis of the manganese, products of hazelnuts, etc. The second 
important sphere would be the production with the specific features, specially designed building materials, artistic and designer products. It should be noted that due to the scarcity of the resources all directions couldn't be developed simultaneously. Thus the choice should be made between two opportunities: high growth of exports or growth of new jobs related to the export. First set of strategies (creation of the higher value added products) creates more jobs, while second set leads to the high growth of exports. These topics should be discussed on the meetings of the Competitiveness Councills.

\subsection{Modern approaches for the Creation of the Export Strategies on the firm level}

As it was mentioned above the export strategies on the firm level became the strategies to survive in the global competitive environment, rather than choice to diversify sales and make more sustainable growth. Different approaches regarding export strategies have been considered, one quite well-known approach named as "Upssalla Model", where sales on the domestic market were considered as the opportunity to gain experience and competitive advantage and only after start exporting. In the scientific publications of the last period have been noted that "Upssalla Model" concerns the Firms growth model introduced by Edith Penrouse. Researches noted "Penrouse not only recognizes that managers (agents) may control and coordinate resources (structures) but also, resources exert influence over human agents and impinge upon managerial initiative".[2]. Thus the basis for the export strategy was the resources of the firm, resourse formulated the strategy and the ways to utilize competitive advantage. It should be noted, that Globalization somehow changed these approaches. Now we could consider firms which are initially operating on the global market and thus economies of scale are utilized through global production. Globalization changed attitudes towards the exports and we could consider quite interesting relations: competitive advantage-exportincreased competitive advantage. Thus the export transforms from the result of the competitive advantage into the source for the competitive advantage. Now it's clear why all companies strive to export as much as possible. Thus export strategies from the firm growth strategies transformed into the strategies to guarantee firms sustainability.

In these conditions it has become vital to evaluate efficiency of the exporting strategies. First of all major criteria should be identified. From different criteria more appropriate ones are: the export growth and the export share in total sales. The first criterion proves the growth of the export from year to year and the second indicates the efficiency of export sales management in comparison with total sales management. It should be noted that for the states with the narrow domestic market the success of the export strategies are vital. Firms face objective obstacles. In case of huge domestic market, fails in the export sales could be easily balanced with the intensification of sales on the domestic market. In the case of Georgia we could consider wine exports. Following the embargo of Russian Federation on Georgian wines, situation became catastrophic, as a) Georgian domestic market is narrow, b) $80 \%$ of wine exports were going to Russian Federation. Thus, in the formulation of the export strategies firms should consider all these topics and try to diversify exports markets as much as possible.

Accordingly, the evaluation of the efficiency of the export strategies means the evaluation of their sustainability which forms the basis for the further economic development. Sustainable export strategies should be oriented to support different activities, these serve as the basis for the sustainability of the strategies. Whiach are these activities?

The Globalization of the world economy had made the competition very tough. Companies couldn't feel secured even on the domestic market. Thus from the second half of the XX-th century different export support activities became fashionable. These support activities could be divided in three main blocks: financial, informational and specific. The financial support activities included special tax exemptions, low interest rate credits, export insurance schemes and etc. These activities have been qualified as the discrimination practice and World Trade Organization member States take the obligation not to use them. The information services included as the general information as well the specific market research activities provided by the respective Governments or with their support. Under the informational activities could be considered special training programmes provided for the export oriented companies staff, while charges claimed to the Government Agencies. The specific activities include the support of the companies in the participation in the different Trade Fairs and Shows, organization of the Promo actions.

As usual nowdays different mechanisms and their combination are usedand a special attention is paid to stay in line with WTO Rules and Procedures. At the same time some questions are always asked: how efficient are these support activities? How we can prove by outcomes that Government funds have been utilized in the best possible way?

Considering these questions the majority of authors put stress on the identical problem of the all export support strategies, this is the fact, the same approach is used with all exporting companies. Using the same approach had its one positive aspects, using the standard approach we are providing standard activities, preventing the different treatment for different exporters and thus preventing the lobbying of the interests. At the same time the identical approach didn't allow to consider specificity of different industries. In practice even two companies interested in the same export market needed different treatment. In the Georgian reality beside the above mentioned problems additional specific factors should be considered. First of all the low number of exporting products, as a result in some industries, Georgia has only one exporter. Thus supporting the export of such products in reality would mean the support of one company. All these 
problems of the export oriented companies transformed in the major decision, which model are the companies going to use: standartization of the international support programmes or their adaptation. Adapted programmes better are focusing on the specific market needs, but there costs are high. Standartized programmes are cheap, but they didn't consider market differences. Attention to this topic is quite high as theoretical as from practical points of view. Some researches showed the positive relations between adaption and performance [6]; some researches showed no relations between two, [7]; and some researches showed the negative relations [8]. To review this topic in detailed manner it would be better to range exporters in order to see the bigger picture and thus undertake adequate decisions.

\subsection{Ranging exporters by some major characteristics}

Exporters could be ranged by different factors. "Drawing from contingency and the organizational learning perspective, the authors develop and test a model of the effects of different forms of international experience - duration, scope and intensity - on the performance outcomes of promotion adaptation" [9].

Above mentioned factors should be defined as follows: duration factor means, when company entered the export operations, volume defines the number of the export markets, intensity defines the dependence on the exports. These factors are creating the practical experience of the exporting company and heavily influencing on the identification of the best support forms for their export activities. For the efficient functioning of the export support strategies crucial factor is the fact who provides the support activities. Low efficiency of the export support strategies could be explained by the fact, that usually providers are governmental structures. For the last period more frequently are used specialized structures. World practice revealed the efficiency by using specialized trading companies. It is very important to use the most appropriate trading intermediary. Just review them in general.

From the beginning trading companies and export manangement companies should be distinguished as they are providing different functions. Trading companies are buying and selling goods while export management companies based on their market intelligence and practice are assisting exporters to define the best buyers. Thus the trading companies are performing all functions of the sellerpackaging, marking products, forming the selling party of the product and etc. Trading companies are very depended on the financial resources which are vital for the reducing costs and taking normal profit. Export manangement companies didn't undertake these functions and mainly assisting exporters to meet the importers' needs. For sure they are giving recommendations for exporters, but the major field of their activities is the creation of the good selling environment based on the market conditions. We also should review the creation of export alliances. Generally speaking there are different types of export alliamces. The simpliest one is when the same product exportes are creating alliance in order to better utilize the opportunities of the new export market.

Quite often these alliances are called horizontal alliances, as the members of the alliance are on the same stage of the value chain. In this alliance the exporters are pursuing the same objectives, as the information on the export country, co-financing of the promo actions, joint market research activities. This form of the export alliance plays more and more minor role. The vertical version of the export alliance is the alliance where the members are on the different stages of the value chain, such as suppliers, producers, trading companies, international marketing intermediaries and financial-banking structures. The participation of the banks becomes crucial, as the participation of the banks supports the solution of the tough financial problem which is connected with the high expenses of the fianancial resources for the exporting operations. The high economical and political risks are putting banks in the position when they are asking higher interest rates for the financial resources for the export operations. In the same manner the participation of the insurance companies in the export alliances should be considered. In this case members of the export alliances are doing their general functions and thus assisting each other to reach the major goal - increase the export sales or enter new export markets. Using the export alliances you face different theoretical and practical problems, for example: how profits would be distributed, who would sell on the export market and etc. As the practice proves there is not any model which could solve all problems. You should consider industry and export markets specifics, take into consideration the existing selling practices. Generally speaking export manangement companies would better support exporters in the obtaining relevant information, in other cases would be better to use trading companies or export alliances. Coming back to Georgian realities, with no doubt firstly the problems with the legislation should be solved. This is absolutely necessary in the case of the export alliances where we don't have any type of legislation. Re-trading companies we could use the status of the special trading companies, but the sphere of the usage should be widened. The majority of the trading companies are profitable while working in both directions such as exports and imports. Also we should consider the fact that in some products (fruits, vegetables) seasonal fluctuations are high. Also we should bear in mind the fact that in Georian exports there is a very high participation of the imported products. Thus the effective usage of the Special Trading Company status needs quite a lot of specific decisions and changes in legislation, first of all in the Tax Code.

Also we should base any type of the export support strategy on the practical needs of the exporters, thus they should define the nature and scope of the support strategies. So the recommendations from the exporters should serve as the basis for the creation of the export support strategies. 


\subsection{The Exporters' Survey Results}

In order to find out the views and the ideas of exporters in 2016 the exporters' interviews were organized. The research was undertaken under the Tbilisi State University Scientific Grant Project "The Ways to Improve Trade Balance of Georgia". The electronic survey was sent to the exporters whose export was more than $1 \mathrm{mln}$. \$ per year. For the sake of clarity the re-exporters have been excluded. The exclusion of re-exporters was done in order to have clear picture of the needs of the exporting community. In the organization of the research Georgian Chamber of Commerce and Industry was actively involved.

Firstly the survey was sent to 433 exporters on the 30th of May, 2016. For the Second time the surveys were sent on the 14th of June, 2016, to 424 companies. 9 companies have been excluded due to the unrelevant contact details. The response was from 44 companies, which represents $10 \%$ of the interviewed companies. According to the Georgian business practice this response rate could be considered as normal and thus the obtained information as valid.

Tha analysis of the survey results leads to some interesting judgements. First of all the total majority of the exporters indicates trade missions on the target markets as the major priority for the export support strategies, also they admit the financial support, as for the geographic direction far east was identified as the major priority, at the same time mentioning $\mathrm{CIS}$ and $\mathrm{EU}$ as the major destinations for Georgian exports. The trade missions organized by the Government support could be considered as the combining of the information and financial support. As the best international practice Government supports the exporters to participate in the Trade fairs or organizes trade mission on the target market. It should be mentioned that in the frame of the Tax reform in Georgia the costs of the participation in trade missions could be considered as a special type of investments and excluded from the profit tax. This would be the serious step to stimulate exporters. Also the participation of the export manangement companies in this process would be crucial. The market information and the knowledge of the export management companies should serve as the basis for the planning of these activities. Also we should review the financial assistance topics. As the number one priority could be nominated - the setting up and the development of the export trading companies. Trading companies will buy and then sell products on their own. This model could quite efficiently work with non brand products, as for the brand products this model wouldn't work effectively. Also the export alliances could solve the financial problems, mainly when banks and insurance companies are participating in the alliances. It should be underlined that these models are increasing sails on the existing markets or utilizing potential of the new export markets. Unfortunately none of these models is contributing to the creation of the new export products. The low number of the exporting products could be identified as the major obstacle for the development of the Georgian exports. The detailed analysis of this problems revealed that the creation of the new export products could be achieved only when all directions of the export supporting strategies work together. These directions could be identified as investment, detailed analysis of the market needs, creation of the unique market offer.[12]

Taking into consideration the Georgian economic realities majority of these problems could be solved through specific export alliances where the international companies would also participate. In this case it would be preferable to introduce the international EMC-s, active participation of the banks should be welcomed in export alliances as they would serve as major investors for the creation of the new export products. Preparing the export offer should be considered the high portion of the services where Georgia has objective competitive advantages. [13] First of all, export strategies will be successful in the agricultural sector. And this will make it possible to fully use the potential of the Georgian agrarian sector which would make possible to live and meet social and economic needs about 2.3 - $4.5 \mathrm{~m}$. people.[14]

We also should review the export support strategies for the services. Here also would be preferable to create export alliances everywhere where it would possible to put together product and service. In the services export where costs of the materials didn't play the important role stress should be put on the certification activities, this would increase competitiveness of Georgian service exporting companies. For the short time period some services' export should be free from the profit tax. 


\section{REFERENCES:}

1. O'Cass, Aron and Craig Juliann (2003), "Examining Firm and Environmental Influences on Export Marketing Mix Strategy and Export Performance of Australian Exporters". European Journal of Marketing, 37 9314) 366-84

2. Best, M.H. Garnsey, E. (1999). Edith penrose, 1914-1996, The Economic Journal, 109,453, pp. 187-201;

3. Garnsey, E, (1995). The Resource Based Theory of the Growth of the Firm, in Ellis, k./ Gregory, a./Ragsdell,G. (eds) Critical Issues in Systems Theory and Practice, New York:Plenum Press, pp. 239-244.

4. Alberto Portugal-Perez, John S. Wilson, WB- Policy Research Working Paper, Export Performance and Trade Facilitation Reform.

5. Gaganidze, G. (2014). "Export Potential and Compettive Advantage”,Scientific Practical Journal “Economy and Business" N3.

6. http://www.intracen.org/itc/goals/Global-Goals-for-Sustainable-Development/

7. Gaganidze G. (2018). Foreign Trade of Georgia, Moldova and the Ukraine with the European Union After Signing The Association Agreement" Ecoforum. 7, N1; http://www.ecoforumjournal.ro/index.php/eco/article/view/710

8. Gaganidze, G. (2015). Competitive advantages of Georgian non-agricultural products on the EU market" The Business \& Management Review; London Vol. 6, Iss. 1, : 26-30. London: The Academy of Business and Retail Management (ABRM).

9. Shoham (1999), "Bounded Rationality, Planning, Standartization of International Strategy and Export Performance: A Structural Model Examination," Journal of International Marketing, 792), 24-50

10. Lages, Sandy D. Jap, and David A. Griffith (2008), "The Role of past Performance in Export Ventures:A Short-TermReactive Approach," Journal of International Business Studies, 39, (2), 304-325

11. Cavusgil, S. Tamer and Shaoming Zou (1994), "Marketing Strategy-Performance Relationship: An Investigation of the Empirical Link in Export market Ventures,' 42(1), 225-245

12. Magnus Hultman, Constantine S. Katsikeas and Matthew J. Robson, (2011). "Export promotion Strategy and Performance: The Role of International Experience." Journal of International Marketing, Vol.19, No.4, pp 17-39.

13. Gaganidze G. (2016). "Georgian Export Potential Utilization on The Eu Market"; Journal of International Management Studies. Vol. 16 Issue 1, p13-18. 6p. www.ebscohost.com

14. Ramishvili B., Koghuashvili P. "The Prospects Of The Development Of Agrarian Sector In The Countries Of South Caucasus In The Conditions Of Economic Global”, Annals Of Agrarian Science 7 (4), 167-169

15. Paata Koguashvili, Badri Ramishvili (2014). "Capacity Of Georgian Village”; Materials of reports made at the international scientific-practical conference held at Paata Gugushvili Institute of Economics of Ivane Javakhishvili Tbilisi State University. 


\section{HOW TO EVALUAT EFFICIENCY OF THE EXPORT STRATEGIES}

\section{GIORGI GAGANIDZE}

https://doi.org/10.35945/gb.2018.05.003

Professor

Ivane Javakhishvili Tbilisi State University, Georgia

giorgi.gaganidze@tsu.ge

\section{BADRI RAMISHVILI}

Associate Professor

Ivane Javakhishvili Tbilisi State University, Georgia

badri.ramishvili@tsu.ge

KEYWORDS: EXPORT STRATEGY FORMULATION AND MANAGEMENT, EVALUATION OF THE EFFICIENCY OF THE EXPORT STRATEGIES

\section{SUMMARY}

The paper reviews the specific topics of the formulation and management of the Export Strategies. Export Strategies became of vital importance for Georgia. After the signing DCFTA with EU Georgian officials were wondering that the export potential of Georgia would be utilized in the best pos- sible way. Unfortunately utilization of export potential is only possible by developing and executing Export STrategies.The author reviews different methods of evaluating the export potential on different markets.In addition to it the article reviews different indicators for evaluating the efficiency of the export strategies. 